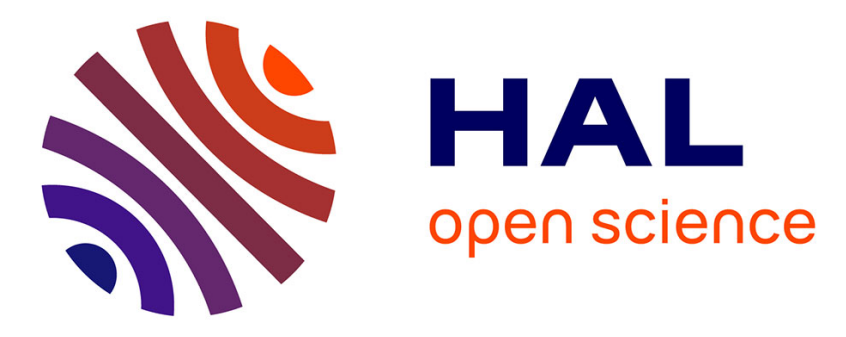

\title{
Effects of land use and climate change on erosion intensity and sediment geochemistry at Lake Lehmilampi, Finland
}

Anna Augustsson, M.J. Gaillard, Pasi Peltola, Florence Mazier, Bo Bergback, Timo Saarinen

\section{To cite this version:}

Anna Augustsson, M.J. Gaillard, Pasi Peltola, Florence Mazier, Bo Bergback, et al.. Effects of land use and climate change on erosion intensity and sediment geochemistry at Lake Lehmilampi, Finland. The Holocene, 2013, 23 (9), pp.1247-1259. halshs-00960101

\section{HAL Id: halshs-00960101 https://shs.hal.science/halshs-00960101}

Submitted on 17 Mar 2014

HAL is a multi-disciplinary open access archive for the deposit and dissemination of scientific research documents, whether they are published or not. The documents may come from teaching and research institutions in France or abroad, or from public or private research centers.
L'archive ouverte pluridisciplinaire HAL, est destinée au dépôt et à la diffusion de documents scientifiques de niveau recherche, publiés ou non, émanant des établissements d'enseignement et de recherche français ou étrangers, des laboratoires publics ou privés. 


\title{
Effects of land use and climate change on erosion intensity and sediment geochemistry at Lake Lehmilampi, Finland
}

\author{
Anna Augustsson, ' Marie-José Gaillard,' Pasi Peltola,' Florence \\ Mazier, ${ }^{2}$ Bo Bergbäck' and Timo Saarinen ${ }^{3}$
}

\begin{abstract}
This paper aims to evaluate the possible relationships between erosion intensity and changes in climate and land use during the past 5.5 cal. $\mathrm{k}$ years at Lake Lehmilampi, eastern Finland. In this study we compare a detailed geochemical sediment record with (I) forest and land use history inferred from the first pollen and charcoal records from Lake Lehmilampi, and (2) existing archaeological surveys and independent proxy-records of climate change in the study region. The physical and geochemical sediment parameters examined include grain size analysis data and 23 chemical elements, determined with four selective extractions and ICP-MS. There are indications of possible human impact in the lake catchment as early as the Neolithic period, c. 3000-2550 $\mathrm{BC}$, but the first undisputable signs are dated to I800-100 BC. Cereal pollen reappears at C. AD I700 and increases rapidly until C. AD I950. The Holocene Thermal Maximum, its end c. 2000 BC, and the 'Medieval Climate Anomaly' were major climate events that had a prominent effect on erosion intensity, while human impact was a more significant factor during the period $3000 \mathrm{BC}-\mathrm{AD} 800$ and from AD I500 onwards. Although signs of changes in erosion intensity found in the sediment were small in this small catchment, they were significant enough to have a clear impact on the fraction of potentially mobile element species. This fraction increases with decreasing erosion intensity, which is probably related to a higher degree of chemical weathering and leaching during periods of decreased erosion.
\end{abstract}

\section{Keywords}

climate change, erosion, geochemistry, human disturbances, land use, varved sediment, weathering

Received I3 September 2012; revised manuscript accepted 2I February 20I3

\section{Introduction}

Varved lake sediments may provide very detailed records of past environmental conditions, both in the lake itself and in its catchment area, providing key information about how the environment responds to natural or human disturbances. Among possible responses, alterations in the flow of elements in the environment, including erosion of surface soils, may be of interest. Erosion, here defined as the physical removal of topsoil particles with surface water runoff, may be affected by climate through changes in water runoff intensity following, for example, altered precipitation patterns. Erosion may also be affected by forest fires (natural or humaninduced), and by other human activities such as deforestation, cultivation or grazing (e.g. Dotterweich, 2008; Enters et al., 2008; Ojala and Alenius, 2005; Tiljander et al., 2003; Zolitschka, 2003).

Element concentrations and sediment accumulation rates in Lake Lehmilampi (eastern Finland) during the mid and late Holocene have been described by Augustsson et al. (2010). The aims of this follow-up paper are to:

(1) Evaluate the possible relationship between erosion intensity and changes in climate and land use during the mid and late Holocene.

(2) Address the effect of erosion intensity on the fraction of potentially mobile element species in the eroded material, inferred from four selective extractions and ICP-MS analysis.
In order to achieve the first objective, we conducted the very first pollen and charcoal analyses at Lake Lehmilampi with the purpose of reconstructing the vegetation and land use history around the site. Moreover, we consulted the existing archaeological record in the study area in order to compare it with the interpretation of the pollen and charcoal records, and we evaluated our multiproxy records in light of published, independent proxy data of regional climate change. A conceptual model of the processes discussed in this study is shown in Figure 1.

\section{The study site}

Lake Lehmilampi is a small lake in northern Karelia, eastern Finland $\left(63^{\circ} 63^{\prime} \mathrm{N}, 29^{\circ} 10^{\prime} \mathrm{E}\right)$ (Figure 2a). It is located in the boreal zone, where many lakes are found to have been sensitive to climate change (Hammarlund et al., 2003; Heikkilä and Seppä,

\footnotetext{
'Linnaeus University, Sweden

${ }^{2}$ Toulouse-Le Mirail University, France

${ }^{3}$ University of Turku, Finland
}

Corresponding author:

Anna Augustsson, Department of Biology and Environmental Science, Linnaeus University, SE-39I 82 Kalmar, Sweden.

Email: anna.augustsson@Inu.se 


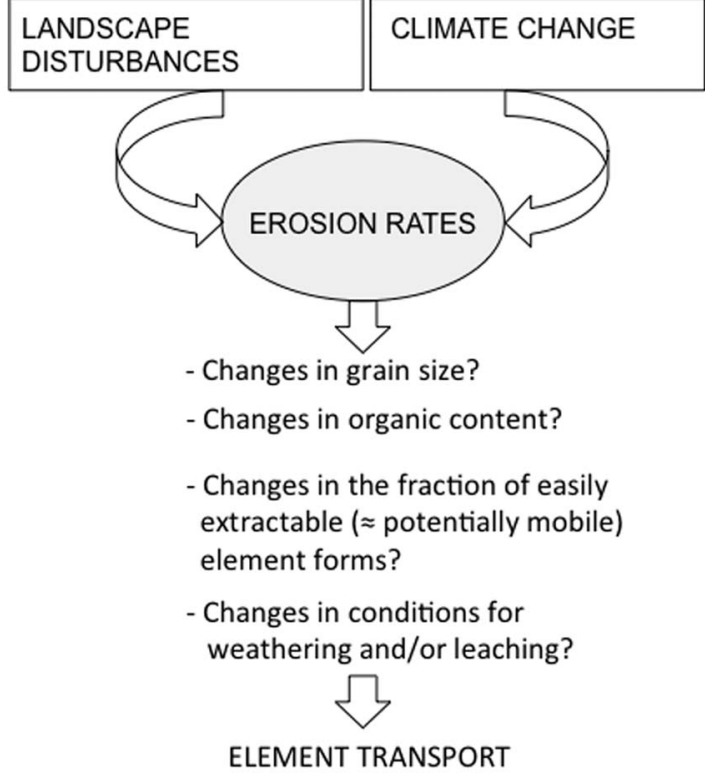

Figure I. Schematic overview of the problem addressed in the paper, see text for explanation.

2003; Itkonen and Salonen, 1994; Seppä et al., 2005). The lake size and catchment are c. $0.15 \mathrm{~km}^{2}$ and $1.5 \mathrm{~km}^{2}$, respectively. Two $11 \mathrm{~m}$ deep basins are located in the southern part of the lake. The dominant tree species in the catchment area are pine and spruce, and the bedrock, consisting of acidic Archaean rocks, is often exposed (Luukkonen, 2003). The soil overburden is composed of thin Quaternary tills and fine-grained sediments may occur in depressions, originating from the time when Lake Lehmilampi was part of Lake Pielinen, one of the largest lakes in Finland, from which it was isolated c. $3100 \mathrm{BC}$ (Haltia-Hovi et al., 2010). The present mean annual temperature is $2^{\circ} \mathrm{C}$, with mean summer (July) temperatures of $16^{\circ} \mathrm{C}$, and mean winter (January) temperatures of $-10^{\circ} \mathrm{C}$. Half of the annual precipitation $(700-750 \mathrm{~mm})$ is deposited as snow. The lake is usually frozen from mid November to mid May, when the spring meltwater discharge accounts for about half of the annual runoff. The lake is surrounded by hills, and the catchment borders are located about $55 \mathrm{~m}$ above the lake water surface. Lake catchments in hilly landscapes tend to be particularly prone to physical erosion. This is obviously the case in Lake Lehmilampi's catchment as the dominant part of the lake sediment is composed of allochthonous mineral matter that has been washed into the lake mainly during snowmelt (Haltia-Hovi et al., 2007). The sediment is varved, starting from the time of the isolation of the lake. There is a continuous increase in varve thickness in the upper $6 \mathrm{~cm}$ of the sediment sequence, but no systematic relationship between depth and varve thickness in the remaining part of the core could be found, which implies that compaction effects are only crucial for the interpretation of the uppermost centimetres of the sediment.

\section{Materials and methods}

Three overlapping subcores were used to extract a $486 \mathrm{~cm}$ long sediment sequence for geochemical analyses. The geochemical characteristics and trends of the entire sediment sequence, hereafter referred to as the 'geochemical core', have been described and discussed by Augustsson et al. (2010). It was only possible to visually identify individual varves in a few segments of the core.
These distinct marker zones enabled the matching of overlapping subcores, but subsampling for geochemical analyses had to be made in continuous $1 \mathrm{~cm}$ segments rather than defined time intervals. The analyses presented in this paper were conducted on sediment from the same subsamples and we adopted the chronology that was established earlier in Augustsson et al. (2010), where the geochemical core was matched against a previosly dated core

\section{Erosion intensity}

Variations in the erosion intensity can be inferred either from the estimates of total mineral matter accumulation available from the x-ray density analyses of the dated core (Haltia-Hovi et al., 2010), or from the variations in ash content measured in the geochemical core. These two variables showed strong positive correlation in the Lake Lehmilampi sediment ( $n=76 ; r=0.78 ; p<0.05$; Augustsson et al., 2010). In order to study the possible relationships between changes in erosion from the catchment and vegetation/ land use changes, it was essential to compare data of exactly the same age. We chose to use the ash content from the geochemical core as an indicator of relative changes in erosion intensity since it could be directly correlated with the results of the chemical leaches and the pollen and charcoal records from the same core. We define high, respectively low erosion intensity as ash content values above the third quartile ( $>87.9 \% ; n=486$; Augustsson et al., 2010) and below the first quartile $(<84.2 \%)$.

\section{Pollen and microcharcoal analysis}

To establish whether major shifts in erosion intensity were related to changes in vegetation and/or land use, 32 subsamples from the geochemical core were selected for pollen and microcharcoal analysis around major shifts in the ash content.

Eight tablets of Lycopodium clavatum spores were added to 1 $\mathrm{g}$ of dry sediment for calculation of pollen concentrations (PCs, pollen grains/g per yr) and pollen accumulation rates (PARs, pollen grains $/ \mathrm{cm}^{2}$ per yr) (Stockmarr, 1971). Sample treatment followed the acetolysis method (Berglund and Ralska-Jasiewiczowa, 1986), and a minimum of 500 pollen grains per sample were identified using keys (Beug, 2004; Punt et al., 1976-2003) and the reference collection at the Laboratory of Palaeoecology at Linnaeus University.

Microcharcoal fragments $>10-25 \mu \mathrm{m}$ and $>25-250 \mu \mathrm{m}$ were counted on the pollen slides following the method used by e.g. Berglund et al. (1991) and Greisman and Gaillard (2008). The sediment from the studied subsamples did not contain any plant macroremains or macrocharcoal fragments $>250 \mu \mathrm{m}$.

Pollen diagrams, including the microcharcoal records, were drawn using the TILIA and TILIAGRAPH programs (Grimm, 1990). The pollen sum $(S)$ used for calculation of percentages includes all pollen of terrestrial plants (Berglund and RalskaJasiewiczowa, 1986). Percentages of charcoal fragments and taxa excluded from the pollen sum were calculated using the pollen sum $S$ with the addition of the count for the excluded taxon/charcoal particle-fraction. Pollen assemblage zones were identified by constrained cluster analysis (Coniss; Grimm, 1987) as implemented in TILIAGRAPH. PCs were calculated in TILIA, and PARs by multiplying PCs with the weight of the $1 \mathrm{~cm}$ thick original sample (g), and dividing the result with the number of years represented in the sample and the area of the core section $\left(\mathrm{cm}^{2}\right)$. Palynological richness (estimated number of pollen taxa $E(T n)$ ) 


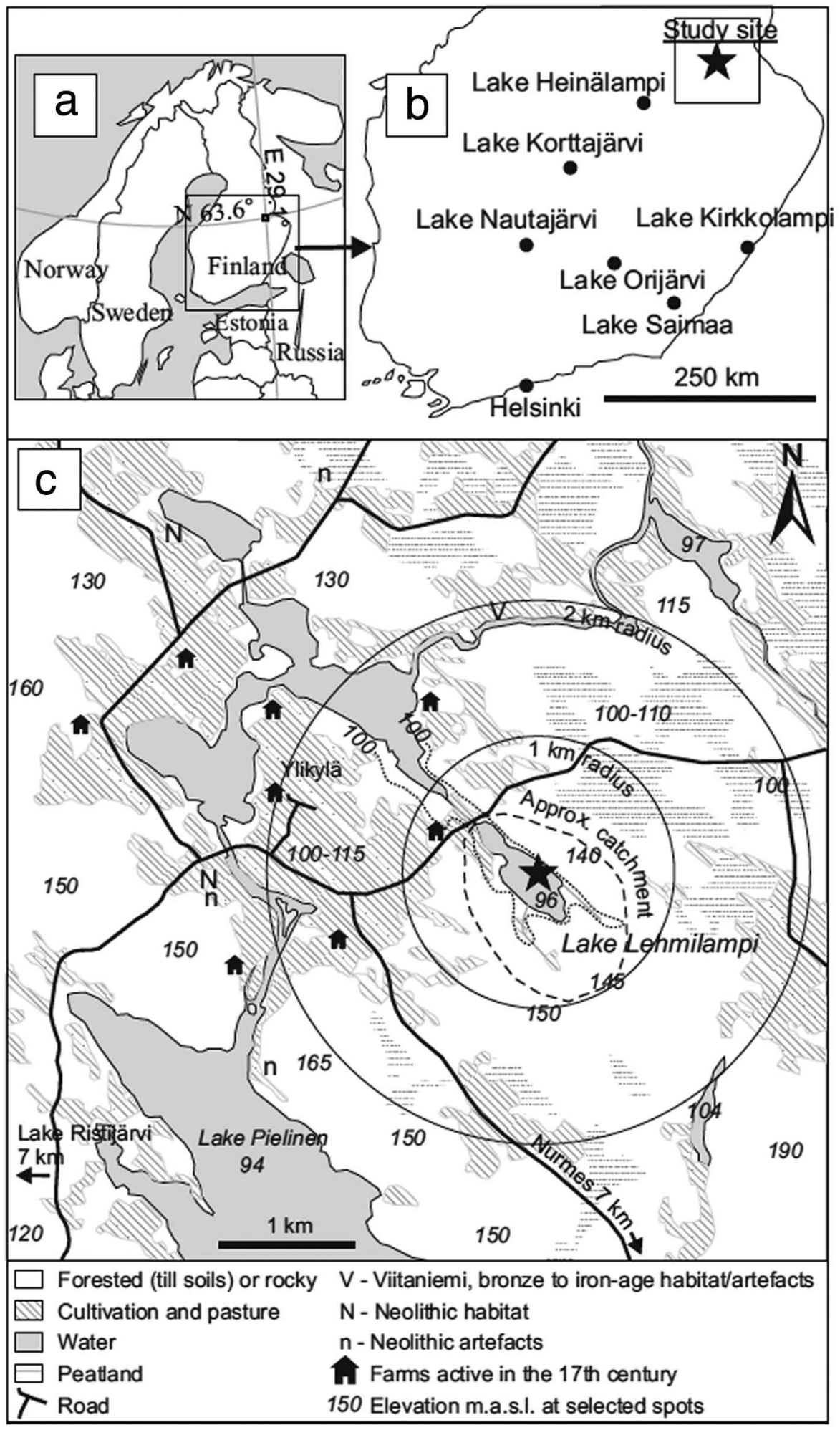

Figure 2. Location of Lake Lehmilampi north of Lake Pielinen in eastern Finland. The dashed line shows the lake catchment as estimated from topographical maps.

was estimated using the rarefaction analysis of Birks and Line (1992). All terrestrial spermatophytes and pteridophytes were included in the analysis.

\section{Grain size analysis}

Size fractionation was determined with a Micromeritics SediGraph 5120 at the Department of Geology at Lund University, Sweden. The SediGraph analysis is based on continuous x-ray scanning of particle settling through a liquid medium of known density and viscosity by applying Stokes law. The principles of the method, reproducibility, and confidence limits are described by Jones et al. (1988). The grain size analysis was conducted on 91 samples from the geochemical core. Prior to analysis, samples were treated with $30 \%$ hydrogen peroxide and $10 \%$ hydrochloric acid to remove organic matter and carbonates respectively. For dispersion of the particles, samples were suspended in $100 \mathrm{ml}$ $0.5 \%$ sodium pyrophosphate and shaken overnight. The 
suspension was filtered through a $63 \mu \mathrm{m}$ sieve and centrifuged to $50 \mathrm{ml}$. Before analysis, samples were treated for $30 \mathrm{~s}$ with an ultrasonic probe. Measurements were made in intervals down to the $0.5 \mu \mathrm{m}$ level. In this paper, however, only the clay size fraction $(<2 \mu \mathrm{m})$ is reported in order to examine whether an increase in small particles occurred during periods of high or low erosion intensity, as fine-grained material should contain a higher proportion of easily weathered element forms than coarse material.

\section{Geochemical analyses}

Material from the same 22 subsamples used for pollen and charcoal analysis was treated for sequential extractions. Three fractions were targeted using the sequential extraction procedure suggested by Hall et al. (1996) and Hall (1998). The first extraction targets elements in exchangeable forms and bound to carbonates $(E x c h)$ by the addition of $1.0 \mathrm{M}$ sodium acetate. The second extraction releases organically bound elements using $0.1 \mathrm{M}$ pyrophosphate $(\mathrm{Org})$, and the third one releases elements associated with amorphous $\mathrm{Fe}$ and $\mathrm{Mn}$ oxyhydroxides by adding $0.25 \mathrm{M}$ hydroxylamine $(\mathrm{Fe} / \mathrm{Mn})$. Total element concentrations were determined after digestion with a mixture of hydrofluoric acid, hydrochloric acid, perchloric acid and nitric acid (Tot). The total extraction was conducted with fresh material instead of analyzing the residual fraction as a final step in the sequence.

The following elements were determined with ICP-AES/MS at Actlabs, Canada: Al, As, Ba, Ca, Ce, Co, Cu, Fe, Ga, K, La, $\mathrm{Mg}, \mathrm{Mn}, \mathrm{Ni}, \mathrm{Pb}, \mathrm{Rb}, \mathrm{S}, \mathrm{Sr}, \mathrm{Th}, \mathrm{U}, \mathrm{V}, \mathrm{Y}, \mathrm{Zn}$. Concentrations in each fraction were recalculated into annual accumulation rates, in a similar way as described for pollen concentrations above. The total potentially mobile fraction (PMF) of elements (\%) was calculated from the annual accumulation rates $\left(\mathrm{mg} / \mathrm{m}^{2}\right.$ per $\left.\mathrm{yr}\right)$ of the different fractions according to:

$$
\mathrm{PMF}=[(\text { Exch }+\mathrm{Org}+\mathrm{Fe} / \mathrm{Mn}) / \mathrm{Tot}) \times 100
$$

\section{Results and discussion}

\section{Land use and fire history}

As one of the study's aims is to compare inferred erosion intensity from the lake catchment with changes in climate, vegetation and land use, it is necessary to define the size of the area around the lake for which the pollen and charcoal records are representative. To date, a concept of the source area exists for pollen assemblages in lake sediments, i.e. the relevant source area of pollen (RSAP) sensu Sugita (1994). The RSAP of small sites can be estimated when there are a number of pollen records from small and large lakes available in the study region, which is not the case here. The radius of the RSAP for small lakes in forested to half open landscapes was estimated to range between $800 \mathrm{~m}$ and $2000 \mathrm{~m}$ in southern Sweden (Hellman et al., 2009a, 2009b; Sugita et al., 1999). Here we assume that the RSAP of Lehmilampi is/was of similar size and, therefore, comparable with the size of the watershed catchment area of the lake (c. $1.5 \mathrm{~km}^{2}$ ). Below, 'study area' refers to the lake catchment area and the RSAP, while 'study region' refers to a larger area around the lake of $2.5^{3}-10^{3} \mathrm{~km}^{2}$.

The definition of the RSAP also implies that it is the smallest area for which a pollen-inferred quantitative reconstruction of vegetation abundance (in percentage cover within the lake's RSAP) can be achieved using the Landscape Reconstruction Algorithm (LRA) of Sugita (2007). The LRA also requires that a number of pollen records from small and large lakes are available in the study region. In this study we thus need to use general insights from quantitative reconstructions in other regions when we interpret the pollen record from Lake Lehmilampi. Although pollen assemblages from small lakes primarily include pollen grains from the local vegetation within the lake's RSAP, a significant fraction of the pollen assemblage (the 'background pollen' sensu Sugita, 2007) originates from the regional vegetation. The background pollen fraction is particularly large when the regional vegetation is characterised by high pollen producers such as Betula and Pinus (e.g. Broström et al., 1998), which is the case in our study region. In such circumstances, non-arboreal pollen (NAP) strongly underestimates the cover of local herbaceous plants (Hellman et al., 2009b; Sugita et al., 1999). Therefore, we assume that the pollen record from Lehmilampi can be interpreted in terms of local vegetation changes, i.e. within the watershed catchment of the lake or slightly larger (a $2 \mathrm{~km}$ radius area around the lake), and that the percentages of NAP in the pollen record at Lehmilampi are an underestimation of the actual cover of open vegetation within the RSAP of the lake.

The source area of microscopic and macroscopic charcoal fragments has been discussed by many authors, but a consensus has so far not been reached (see Greisman and Gaillard, 2008, for a detailed discussion). Here we assume that the size fractions $10-\leq 25 \mu \mathrm{m}$ and $>25-250 \mu \mathrm{m}$ roughly represent regional respectively local fire activity. In a study of Lake Ristijärvi $(7 \mathrm{~km}$ from Lehmilampi; Figure 2c), it was shown that the local forests burned in intervals of 220-260 years between c. $4350 \mathrm{BC}$ and $\mathrm{AD} 1450$ (Pitkänen et al., 2002). Similar fire regimes probably characterised most of the forests of the study region, including our study area. Thus the small-size fraction of microcharcoal in the record from Lehmilampi probably represents primarily the background microcharcoal input from regional fires.

We interpret the simultaneous occurrence of pollen indicators of human impact (following Gaillard, 2007), pollen cereals (Cerealiatype, Hordeum-type and/or Secale) and high values of large microcharcoal particles $(>25-250 \mu \mathrm{m})$ (Figure $3 \mathrm{a}$ ) as an indication of local slash-and-burn cultivation (Cornell, 2007). However, the occurrence of pollen from light-demanding plants alone - without a simultaneous occurrence of pollen from cereals - may just as well represent natural local disturbances (i.e. fire, wind, disease, etc.). The latter needs to be kept in mind when interpreting pollen data in terms of land use and human impact. Changes in palynological richness (estimated number of pollen taxa $E(T n)$, see methods) are assumed to provide an estimate of changes in plant diversity at the biotope/vegetation level. $E(T n)$ was shown to increase with disturbance intensity up to an intermediate level of disturbance (e.g. Berglund et al., 2008). Thus we assume that a high $E(T n)$ is an additional indicator of disturbance in the record from Lehmilampi.

Below we refer to the archaeological chronology developed for the inland areas of eastern Finland. The major characteristics of the local pollen assemblage zones (LPAZs) are summarised in the electronic supplementary material (Table 1, available online). The pollen diagrams (Figure 3a, b) include the most abundant pollen types. Rare pollen findings are presented in the electronic supplementary material Table 2 (available online). We inferred four major periods of vegetation/forest disturbance (natural or human-induced); the three oldest periods are separated by two phases lacking signs of disturbances. The two last periods follow each other in time, but are different in character. Below we mainly discuss the inferred periods of vegetation/forest disturbance. 


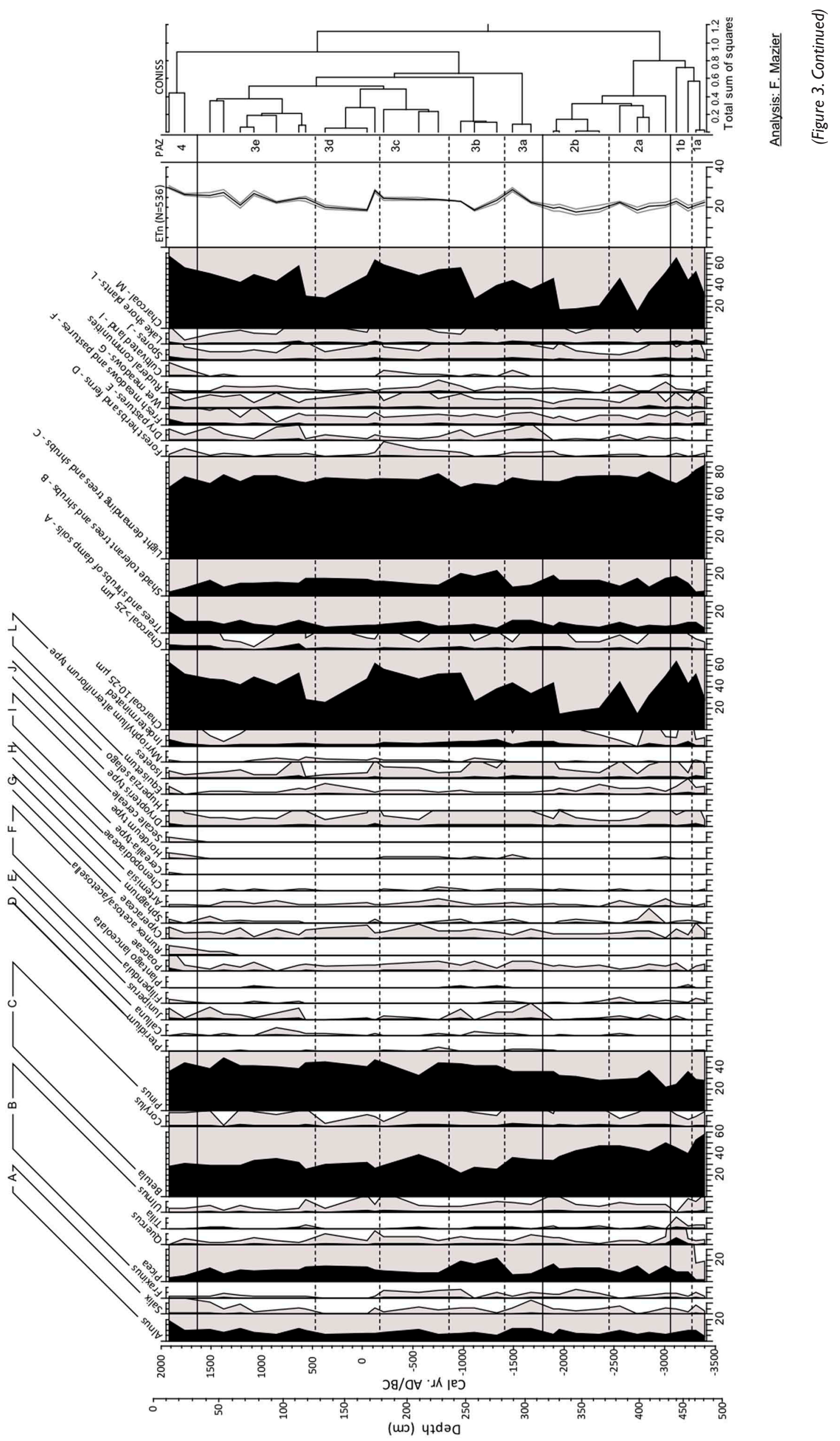




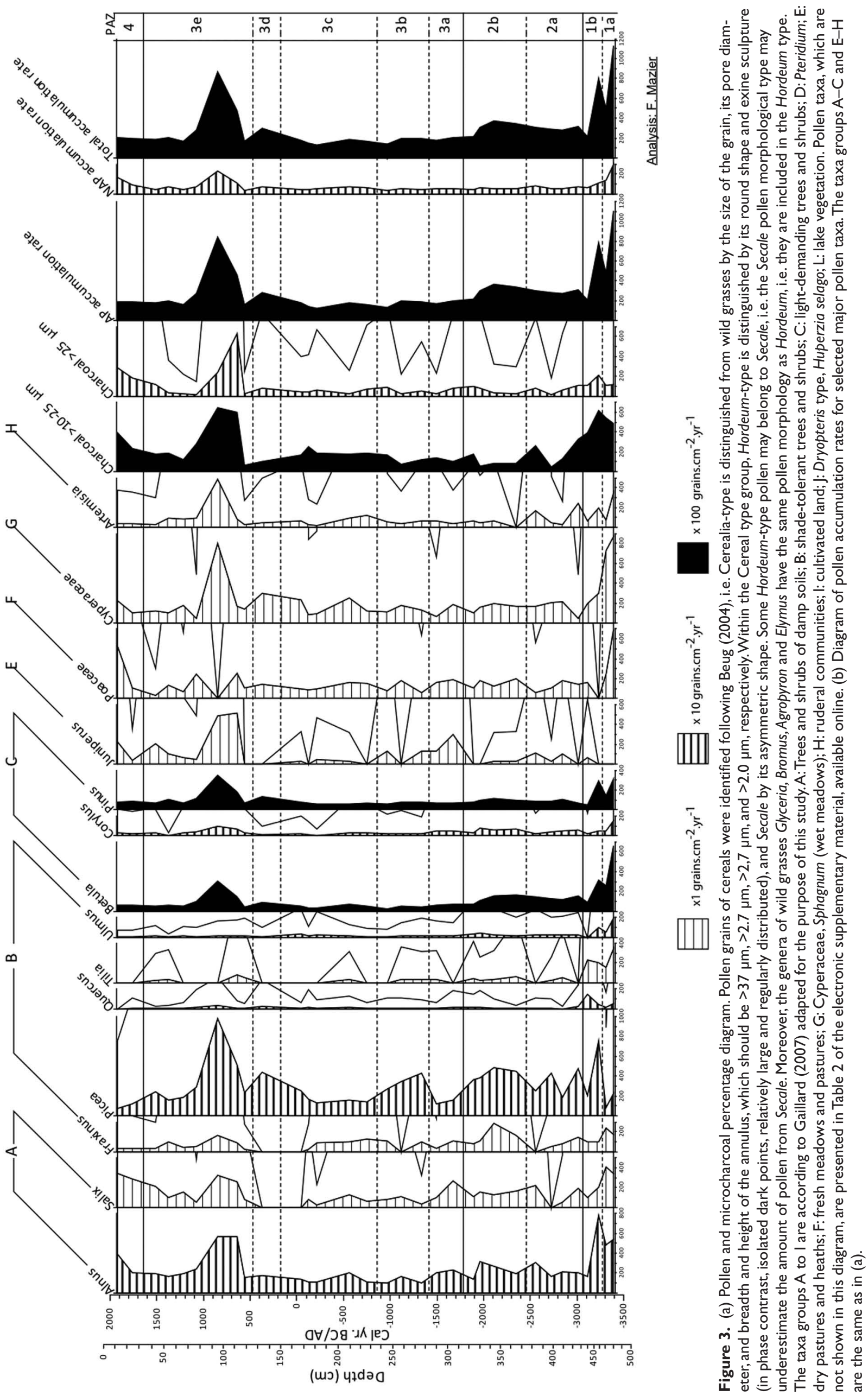


Table I. Results of the sequential leaches, separated for samples with high erosion intensity (above the third quartile, Q3, of the original ash content data, $n=493$ ) and low erosion intensity (below the first quartile, QI). The columns to the left show the sum of the three potentially mobile phases, in percent of the total accumulation of the element (Eq. I). The relative difference between low and high erosion samples (Rel Diff) is given as the ratio of the $<\mathrm{Q} I />\mathrm{Q} 3$ values. Values above I mean that the total fraction of potentially mobile forms was higher in the low erosion rate material. As the values of the table are rounded, the decimals of the Rel Diff are in a few cases not corresponding to the $<\mathrm{Q} I />\mathrm{Q} 3$ of the tabled data. The three following columns state corresponding results for the three individual extractions.

\begin{tabular}{|c|c|c|c|c|c|c|c|c|c|c|c|c|}
\hline & \multicolumn{3}{|c|}{$\begin{array}{l}\text { Sum of potentially mobile } \\
\text { forms }\end{array}$} & \multicolumn{3}{|c|}{$\begin{array}{l}\text { Exchangeable forms and } \\
\text { bound to carbonates }\end{array}$} & \multicolumn{3}{|c|}{ Forms in organic complexes } & \multicolumn{3}{|c|}{$\begin{array}{l}\text { Forms associated with } \\
\text { amorphous oxyhydroxides of } \\
\text { Fe and } \mathrm{Mn}\end{array}$} \\
\hline & $>$ Q3 & $<\mathrm{QI}$ & Rel diff & $>$ Q3 & $<\mathrm{Ql}$ & Rel diff & $>$ Q3 & $<\mathrm{Q}$ & Rel diff & $>$ Q3 & $<\mathrm{Ql}$ & Rel diff \\
\hline $\mathrm{Sr}$ & 2.6 & 7.0 & 2.7 & 1.3 & 4.1 & 3.3 & 0.67 & 1.35 & 2.0 & 0.79 & 1.56 & 2.0 \\
\hline $\mathrm{Ca}$ & 7.8 & 16.7 & 2.1 & 3.4 & 10.5 & 3.1 & 0.7 & 2.6 & 3.7 & 3.6 & 3.6 & 1.0 \\
\hline Co & 29 & 53 & 1.8 & 9.5 & 23.3 & 2.5 & 12 & 18 & 1.5 & 7.7 & 11.5 & 1.5 \\
\hline $\mathrm{Zn}$ & 20 & 35 & 1.8 & 5.9 & 12.7 & 2.2 & 8.9 & 13.3 & 1.5 & 5 & 8.8 & 1.8 \\
\hline $\mathrm{Ni}$ & 13 & 22 & 1.7 & 5.3 & 8.1 & 1.5 & 5.0 & 9.4 & 1.9 & 2.4 & 4.4 & 1.8 \\
\hline $\mathrm{Ga}$ & 15 & 24 & 1.6 & 7.6 & 12.2 & 1.6 & 4.3 & 7.5 & 1.7 & 2.7 & 4.3 & 1.6 \\
\hline V & 21 & 33 & 1.5 & 4.3 & 1.2 & 0.3 & 14 & 21 & 1.5 & 3.8 & 11.0 & 2.9 \\
\hline$Y$ & 24 & 37 & 1.5 & 9.7 & 11.5 & 1.2 & II & 19 & 1.7 & 3.6 & 6.2 & 1.7 \\
\hline $\mathrm{Mg}$ & 3.1 & 4.7 & 1.5 & 0.44 & 1.57 & 3.6 & 1.7 & 2.5 & 1.5 & 0.93 & 0.64 & 0.7 \\
\hline $\mathrm{Ba}$ & 16 & 24 & 1.5 & 3.5 & 4.8 & 1.4 & 2.1 & 3.4 & 1.6 & 10 & 16 & 1.5 \\
\hline $\mathrm{Rb}$ & 1.7 & 2.3 & 1.4 & 0.27 & $0.4 I$ & 1.5 & 0.85 & 1.16 & 1.4 & 0.58 & 0.77 & 1.3 \\
\hline $\mathrm{La}$ & 26 & 34 & 1.3 & 6.6 & 7.2 & I.I & 14 & 17 & 1.3 & 5.8 & 9.3 & 1.6 \\
\hline $\mathrm{Fe}$ & 32 & 42 & 1.3 & 5.2 & 4.9 & 0.9 & 22 & 25 & I.I & 8.8 & 12.6 & 1.4 \\
\hline $\mathrm{K}$ & 2.8 & 3.6 & 1.3 & 0.56 & 0.83 & 1.5 & 1.9 & 2.4 & 1.2 & 0.32 & $0.4 I$ & 1.3 \\
\hline$M n$ & 73 & 92 & I. 3 & 59 & 71 & 1.2 & 8.9 & 14.5 & 1.6 & 5.1 & 6.8 & 1.3 \\
\hline $\mathrm{Ce}$ & 33 & 42 & 1.3 & 8.4 & 9.0 & I.I & 19 & 22 & 1.2 & 6.5 & 10.7 & 1.6 \\
\hline$U$ & 38 & 44 & I.I & 20 & 22 & I.I & 13 & 18 & 1.5 & 5.6 & 3.1 & 0.6 \\
\hline Th & 24 & 26 & I.I & 6.1 & 3.2 & 0.5 & 17 & 22 & 1.3 & I.I & 0.86 & 0.8 \\
\hline $\mathrm{Cu}$ & 32 & 32 & 1.0 & 5.0 & 3.4 & 0.7 & 21 & 23 & I.I & 5.4 & 6.1 & I.I \\
\hline$S$ & 67 & 61 & 0.9 & 32 & 24 & 0.8 & 33 & 36 & I.I & 2.1 & 1.8 & 0.9 \\
\hline $\mathrm{Pb}$ & 49 & 38 & 0.8 & 6.1 & 2.9 & 0.5 & 23 & 15 & 0.6 & 20 & 21 & 1.0 \\
\hline As & 16 & 11 & 0.7 & 7.2 & 3.8 & 0.5 & 3.1 & 0.8 & 0.3 & 5.2 & 6.4 & 1.2 \\
\hline
\end{tabular}

Neolithic time, c. 3000-2500 BC (LPAZ 2a). The first possible indications of human impact can be seen as early as the Neolithic time, between c. 3000 and 2500 BC (Figure 3a, b). Low but regular occurrences of Juniperus, Poaceae, Artemisia, Chenopodiaceae, Plantago major, Rumex acetosalacetosella, Filipendula and Ranunculus acris are found, together with one finding of Hordeum type pollen and a few grains of Anemone nemorosa group, Anthriscus sylvestris, other Apiaceae, Geum and Plantago major (electronic supplementary material, Table 2, available online). All these taxa may have grown in forest openings created by humaninduced disturbance (possibly cattle grazing) or natural disturbance. The Hordeum pollen-morphological type includes some genera of wild grasses (see methods above) and, therefore, is not an absolute proof of the cultivation of cereals. The current general opinion is that people were present in southern and eastern Finland since the Neolithic time, but that human influence on the landscape remained negligible until c. AD 1000 (the Viking Age) (Seppä et al., 2009). At Lake Ristijärvi (7 km from Lehmilampi), the earliest findings of human presence consist of low values of cereal pollen in sediment from the 13th century (Poutiainen et al., 1994). Nevertheless, a number of artefacts and settlements dated to the Neolithic were found not far from the lake catchment (Figure 2c) (Finland's National Board of Antiquities, 2012). To date, the earliest occurrence of cereal pollen grains in Eastern Finland is from the area of Lake Saimaa and was dated to c. $1400 \mathrm{BC}$ (early Metal Period) (Vuorela, 1999; Vuorela and Kankainen, 1993).

LPAZ 2b (2500-1800 BC) is characterised by more sporadic occurrences of human-impact pollen indicators and no findings of cereal pollen. Therefore, it is interpreted as a period with little or no human/natural disturbance.

Early Metal Period, c. 1800-100 BC (LPAZ 3a-3c). The period of 1800-100 BC contains two episodes (LPAZ 3a 1800-1400 BC and LPAZ 3c 850-100 BC) with, in comparison to LPAZ 2 and 3d, relatively high values of large microcharcoal particles $(>25-250$ $\mu \mathrm{m})$, lower pollen values of Picea, slightly higher pollen values of Gramineae and Cyperaceae, and regular occurrences of Juniperus, Artemisia, Chenopodiaceae, Hordeum-type and Pteridium. Sagina procumbens group, Geum and Cannabis sativa occur with few grains (electronic supplementary material, Table 2, available online). There is also a slight rise in $E(T n)$ values. A decrease in Picea has been explained earlier by its intolerance to fire (Grönlund, 1995) and Juniperus was proposed as one of the best indicators of grazing in Finland (Haegström, 1990). Furthermore, continuous findings of Pteridium have often been used as an indication of cultivation involving fire (Grönlund, 1995; Pitkänen, 1999). The more regular occurrence - and often larger amounts - of many of the human-impact indicators, as well as their higher diversity, the regular occurrence of Hordeum type and Pteridium, and the relatively high values of microcharcoals $>25-250 \mu \mathrm{m}$ during the two episodes (LPAZ $3 \mathrm{a}$ and $3 \mathrm{c}$ ) all suggest that human interference is a probable explanation, possibly due to slash-and-burn cultivation and cattle grazing. The LPAZ $3 \mathrm{~b}, 1400-850 \mathrm{BC}$, with higher values of Picea, lower values of Gramineae and $E(T n)$, and the absence of Pteridium, may indicate a period with fewer fires and weaker human impact in terms 
of slash-and-burn, although most of the human-impact indicators mentioned above are still present, suggesting that cattle grazing still occurred in the study area.

Lake Heinälampi is the closest site with indications of human impact in the pollen record dated to c. 1300 BC (Figure 2b; Grönlund et al., 1992). Indications of human impact dating back to that time were also found in the area of Lake Saimaa (1400 BC), Lake Orijärvi (1600 BC; Alenius et al., 2008), and Lake Kirkkolampi (1950-1800 BC; Alenius and Laakso, 2006). The nearest archaeological evidence of settlement from that period in the study area is from Viitaniemi (Figure 2c).

LPAZ 3d (800 BC-AD 600) is characterised by sporadic occurrences of human-impact pollen indicators, no findings of cereal pollen, and low charcoal and $E(T n)$ values. It is therefore interpreted as a period with little or no human disturbances.

Migration period (middle Iron Age) to late Middle Ages, AD 6001500 (LPAZ 3e). Between c. AD 600 and 1500, the percentages of Picea decrease, Artemisia is represented during the entire period, and there are rare findings of Apiaceae, Aster type, Epilobium angustifolium type, Galium type, Geum, Potentilla type, Ranunculus acris group, Silene vulgaris group, and Cannabis sativa (electronic supplementary material Table 2, available online). The values of $E(T n)$ also increase slightly, However, Pteridium is rare and there are no findings of Cerealia-type which, together with the generally low values of large microcharcoal particles, indicates that slash-and-burn was not practiced locally during most of the period. However, the high number of herb pollen taxa does indicate some disturbance and might reflect the occurrence of cattle grazing in the forest.

A large body of archaeological and palaeoecological records from southern and eastern Finland clearly demonstrate that farming started to develop at many sites during the Iron Age and increased in intensity during the Middle Ages (Alenius et al., 2008; Grönlund, 1995; Grönlund et al., 1992). Sporadic slashand-burn agriculture of a similar age (AD 900) has been documented earlier in pollen records from northern Karelia (Grönlund, 1995; Grönlund and Asikainen, 1992; Grönlund et al., 1992). Cereal cultivation during that period was also found south of our study area (Figure 2b), at Lake Kirkkolampi (AD 300; Alenius and Laakso, 2006) and Lake Orijärvi (AD 600, Alenius et al., 2008). The reason why slash-and-burn was not practiced in the catchment of Lehmilampi at that time, but was practiced earlier (early Metal Period) and later (from c. AD 1500), is not known.

AD 1500-Modern times (LPAZ 4). A study by Pitkänen et al. (2002) indicates a drastic increase in forest fires about 500 years ago associated with stronger human impact in the area. The increase in percentage and accumulation rate of large microcharcoal particles c. AD 1500 in our study site, concurrent with an increase in Salix, Juniperus and Rumex, may be related to the same trend. From c. AD 1700, the pollen record indicates the cultivation of rye (Secale) and possibly barley (Hordeum type). Poaceae and Rumex increase from c. AD 1800 and reach their highest values in the profile, while Picea has very low values. Some indicators of human impact occur for the first time, including Anthemis type, Compositae SF Cichorioidae, and Sinapis type (electronic supplementary material Table 2, available online). Slash-and-burn was probably common locally from $\mathrm{AD} 1700$. The continuous increase of $E(T n)$ values over the last 300 years suggests that these land use changes resulted in a more fragmented and open forest vegetation with a higher biodiversity (Berglund et al., 2008). This interpretation is supported by the first mention of the town of Nurmes in written sources dating to $\mathrm{AD} 1556$, the known existence of several farms in the area during the 17th century (Figure 2c), and the documented expansion of agriculture during the 18th century. During the 17 th century, each farm had cultivated fields, and slash-andburn was the dominant practice. Efforts were soon made to forbid slash-and-burn because of a wood shortage in many parts of southern and eastern Finland. Slash-and-burn decreased rapidly from mid AD 1800 onwards and was largely replaced by modern agriculture and sylviculture. The changes observed in the pollen record are also most probably related to the increase in the human population in North Karelia and the parallel increase in the amount of rye sown on arable land.

\section{Controls on erosion intensity}

Lake Lehmilampi was chosen for this study because the effects of within-lake processes on the sediment are assumed to have been small compared with the effects caused by changes in the catchment. Although there is a small fraction of organic matter in the clastic-organic varves that may originate primarily from authochtonous primary production (Haltia-Hovi et al., 2007), Lake Lehmilampi is a deep oligotrophic, clear-water lake where the material deposited in the deep basins is dominated by allochthonous mineral matter. The sediment is characterized by a low sediment accumulation rate and bioturbation from benthic animals is negligible. Moreover, the lake's large water volume in relation to its small catchment area implies a lake water retention time that allows for precipitation and accumulation in the lake sediment of suspended particles originating from the surroundings. Obviously, oligotrophic lakes may exhibit internal changes over time as a result of climate change. It is well known that, for example, changes in temperature or water stratification can affect the redox potential and leakage of elements from the sediment into the overlying water (Wetzel, 2001). However, no signs of such changes were detected in the sedimentary data and, therefore, we assume that the major processes affecting the geochemical properties of the lake sediments are terrestrial.

When discussing erosion intensity at Lake Lehmilampi we need to remember that changes are occurring in a relatively stable environment as indicated by the preservation of a varved sequence. The input rates cannot have reached extremes, otherwise the varves would not have been preserved. Also, the indicators of human disturbance in the sediment are assumed to originate from a relatively small area corresponding more or less to the size of the lake watershed catchment $\left(1.5 \mathrm{~km}^{2}\right)$. The latter probably had a marginal location in relation to the major human activities around farms and villages, thus the disturbances in terms of open land and soil erosion were probably never very large in the lake catchment itself. Still, significant changes were registered in the sediment sequence.

The inferred erosion record at Lake Lehmilampi is shown in Figure 4. The highest erosion intensities coincide with periods characterised by human disturbance and local fire. The maximum erosion intensity is found during the most recent centuries, together with palynological evidence of cereal cultivation from AD 1700 onwards (possibly starting c. AD 1500). Erosion intensities that were almost as high are found c. 900-100 BC, along with indications of slash-and-burn. A third period of high erosion 


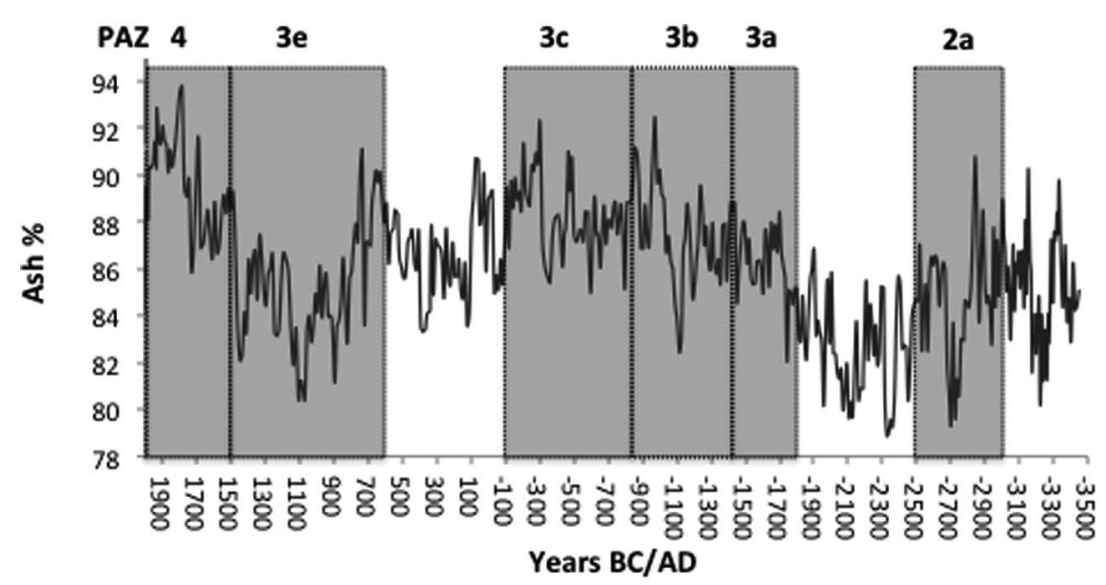

Figure 4. Inferred variations in erosion intensity, illustrated by ash content. Grey zones indicate the periods of natural or human-induced disturbances of the catchment and an increased openness of the landscape. For description of pollen assemblage zones (PAZs), please see the Land Use and Fire History Discussion.

intensity (AD 600-800) also includes signs of local fire, although the slash-and-burn practice is not confirmed by findings of cereal pollen in this case. During these three phases, human impact and the use of fire in the lake catchment may have caused significant destabilization of the surface soils and led to an increase in the outwash of detrital matter.

The $900-100$ BC phase is the last part of a long period of human disturbances in the forest that started as early as c. $1800 \mathrm{BC}$. Erosion intensity was lower at the beginning of the period, possibly because of less intense human impact close to the lake. However, the erosion intensity started to increase by c. 2100 BC, before the first signs of human disturbances are seen. This initial increase may have been partly climate-induced. A significant climate shift towards colder and more humid conditions in Scandinavia between 2000 and 2500 $\mathrm{BC}$, marking the end of the long-lasting Holocene Thermal Maximum (HTM), has been described in numerous studies (e.g. Dahl and Nesje, 1996; Digerfeldt, 1988; Hammarlund et al., 2003; Korhola, 1995; Korhola et al., 1996; Nesje et al., 2001; Seppä et al., $2005,2009)$. This temperature decrease was also accompanied by more humid conditions, as indicated by the development of peatlands in Finland (e.g. Korhola, 1995; Korhola et al., 1996) and a rise in lake levels in southern Sweden (e.g. Digerfeldt, 1988; Eronen et al., 1999; Hammarlund et al., 2003; Seppä et al., 2005). Thus the increase in erosion rates observed from $2100 \mathrm{BC}$ may be due to colder climate and increased precipitation. At the latitudes of Lehmilampi an increase in the duration of the winter season would have led to higher snow accumulation and thus increased surface runoff during snowmelt. An increased detrital input at the HTM termination has also been found in the varves of Lake Nautajärvi in central southern Finland, starting c. 2000 BC and followed by a continuous increase in mineral matter accumulation until c. AD 1 (Ojala and Alenius, 2005), which corresponds well to the trend seen at Lake Lehmilampi. An increased input to lake sediments has also been seen c. 2050 BC in Lake Igelsjön in southern Sweden (Jessen et al., 2005), and somewhat later, c. 1760 BC, in Lake Sarsjön in northern Sweden, which supports the theory of climate causing the increase in erosion intensity in Scandinavia at the end of the HTM.

The two periods with the most significant reduction in erosion intensity were found between 3000-2500 BC and $\mathrm{AD} 800-1500$. There is no indication of local fire during these two periods, which suggests that slash-and-burn was not practiced in the surrounding area. Forest grazing might explain the occurrence of human-impact pollen indicators for the more recent of these two periods. The most likely factor affecting the two low-erosion periods should be sought on a regional level. First, because there are periods with higher erosion intensity in the record that lack human disturbances (c. $100 \mathrm{BC}-\mathrm{AD}$ 600). And in addition, low erosion intensities were also indicated in the record from Lake Nautajärvi during the same two periods (Ojala and Alenius, 2005). What the two periods have in common is that they were relatively warm and dry. The older of the two is found during the HTM, which has already been discussed above. The second one coincides with the 'Medieval Climate Anomaly' (MCA, AD 950-1250, Mann et al., 2009). This lower erosion intensity during the MCA was also recorded at Lake Korttajärvi and Lake Nautajärvi in south-central Finland (Figure 2b; Ojala and Alenius, 2005; Tiljander et al., 2003). As erosion intensity once again starts to increase around Lake Lehmilampi c. AD 1500, indicators of local fire suggest that slash-and-burn is practiced again. However, the role of human impact cannot be disentangled from the possible effect of the 'Little Ice Age' starting c. AD 1450 (Mann et al., 2009).

Climate change obviously played a significant role in the sediment accumulation and composition of Lake Lehmilampi during some periods of the Holocene. This was also shown by HaltiaHovi et al. (2007), who found a strong positive correlation between varve thickness and solar activity. However, varve thickness is controlled mainly by the accumulation of organic matter, which has a high water content (Renberg et al., 1984). The accumulation of organic matter is mainly a function of autochtonous primary production and decomposition rates, and hence not suitable for tracking changes occurring in the catchment area. HaltiaHovi et al. (2007) also present the results of mineral matter accumulation, which matches the ash content profile discussed in this paper. However, since their comparison with solar activity was not based on changes in the input of detrital mineral matter, their study and ours complement each other and show that lake sediments are controlled by both limnological processes (varve thickness) and terrestrial processes (mineral matter accumulation), where climate might be a strong forcing factor on processes both within the lake and in its catchment, but where the processes within the lake's catchment may also be strongly affected by human disturbances, natural forest fires, and other phenomena influencing both the erosion intensity and the physical and geochemical composition of the lake sediments. 


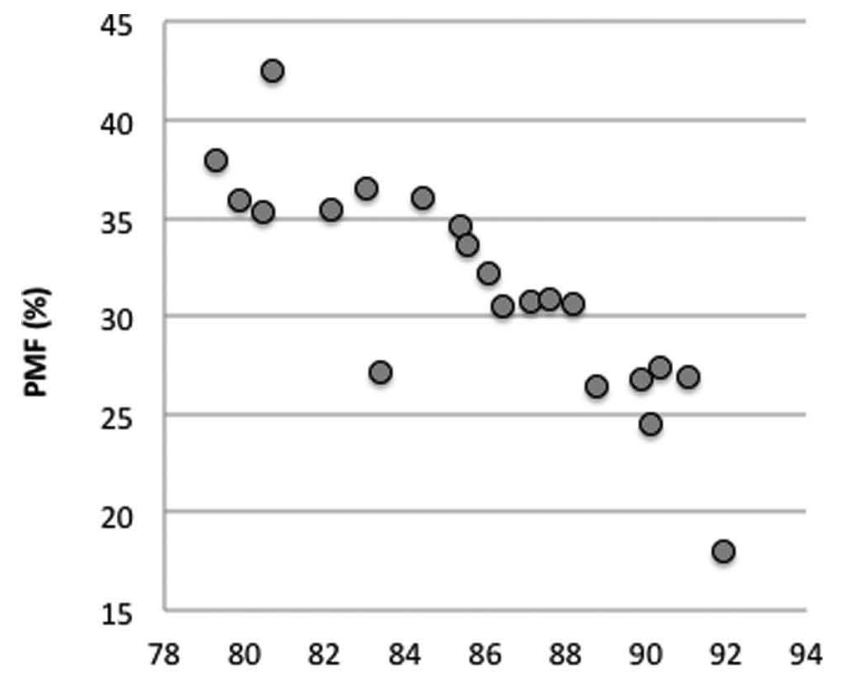

Ash content (\%)

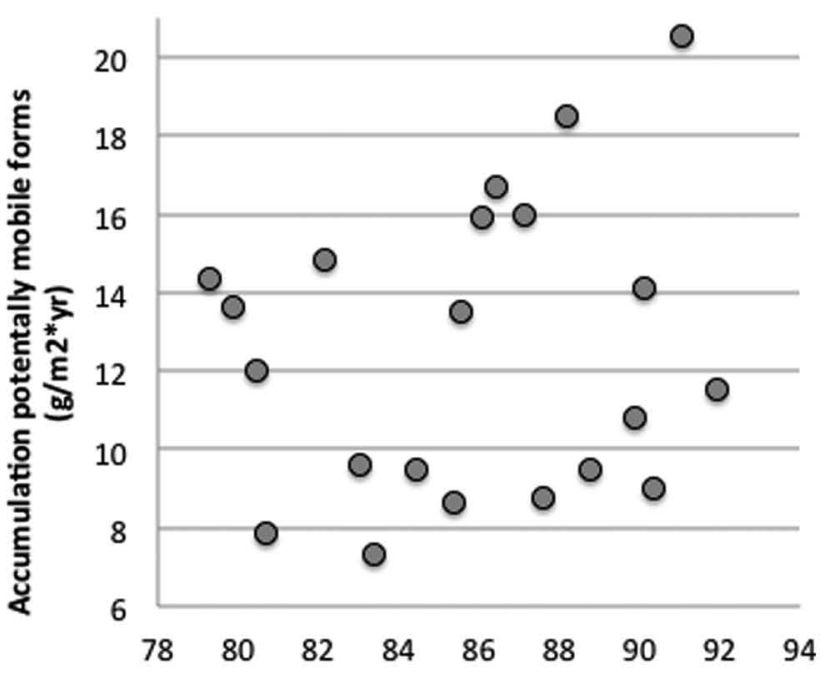

Ash content (\%)

Figure 5. The total fraction of potentially mobile element forms (sum of the three sequential leaches for $\mathrm{Al}, \mathrm{As}, \mathrm{Ba}, \mathrm{Ca}, \mathrm{Ce}, \mathrm{Co}, \mathrm{Cu}, \mathrm{Fe}, \mathrm{Ga}$, $\mathrm{K}, \mathrm{La}, \mathrm{Mg}, \mathrm{Mn}, \mathrm{Ni}, \mathrm{Pb}, \mathrm{Rb}, \mathrm{S}, \mathrm{Sr}, \mathrm{Th}, \mathrm{U}, \mathrm{V}, \mathrm{Y}$ and $\mathrm{Zn}$ ) as a function of the rate of catchment erosion. Ash content values are used as a proxy for catchment erosion from the same samples, which were sequentially leached.

\section{An increase in potentially mobile element forms during low erosion intensity}

There is a clear negative correlation between the total potentially mobile fraction (PMF) of elements and the erosion intensity $\left(r_{\mathrm{s}}=-0.87 ; p<0.01 ; n=22\right)$ (Figure $\left.5 \mathrm{a}\right)$. Each element's PMF is given in Table 1. The PMF varies from 10 to $90 \%$ depending on the element, which means that a substantial fraction of all elements was deposited in relatively unstable and easily leachable forms. The only elements with low values were $\mathrm{Sr}, \mathrm{Mg}, \mathrm{K}$ and $\mathrm{Rb}$, all common in stable silicate minerals. All elements except $\mathrm{S}, \mathrm{Pb}$ and $\mathrm{As}$ had a higher $\mathrm{PMF}$ in samples from periods with low erosion intensity. Of the 22 samples, the one with the highest erosion intensity contained a PMF of $18 \%$, while the sample representing the lowest erosion intensity had a PMF of $38 \%$ (Figure $5 \mathrm{a}$ ). The average annual accumulation of sediment was estimated to be $550 \mathrm{~g} / \mathrm{m}^{2}$ per yr for the sample with the highest estimate of erosion intensity, and $210 \mathrm{~g} / \mathrm{m}^{2}$ per $\mathrm{yr}$ ( i.e. c. $40 \%$ of the $550 \mathrm{~g}$ ) for the sample with the lowest estimate of erosion intensity (Augustsson et al., 2010). However, the higher PMF in the samples characterised by low erosion intensity compensates for the lower total sediment accumulation; thus the total accumulation of potentially mobile forms did not change much with changes in erosion intensity (Figure $5 \mathrm{~b}$ ). For example, the $18 \%$ PMF in the sample with the highest erosion intensity corresponds to $100 \mathrm{~g} / \mathrm{m}^{2}$ per yr of potentially mobile forms, and the corresponding value for the sample with the lowest erosion intensity is $80 \mathrm{~g} / \mathrm{m}^{2}$ per yr.

The decrease in PMF with erosion intensity could result from an increased input of coarser particles. As these particles should be more resistant to the leaching procedures applied, they would dilute more easily extractable forms. However, the lower PMF at high erosion intensities may also depend on altered conditions for leaching from the catchment. The impact of grain size effects and leaching are discussed below.

Effects of grain size changes on potentially mobile element forms. The lowest erosion intensities found during warm and dry periods might be explained by comparatively low surface water runoff. If this is the case, the average grain size of the eroded material might be lower during such periods, which has been indicated in the sediments of Lake Nautajärvi (Ojala and Francus, 2002). Since finer fractions are enriched in the species that were targeted in the sequential extraction, i.e. the potentially mobile forms, the high PMF values at low erosion intensity could result from a higher content of fine particles. However, no correlation was found between the ash content and the particle size. Figure 6 shows the results for the clay-size fraction $(<2 \mu \mathrm{m})$, but the same lack of relationship appeared also when larger fractions were considered. The lack of systematic changes in the mechanical sorting of the fine fraction between periods of high and low erosion intensity was unexpected.

Effects of weathering and/or leaching. Is it then possible to explain the change in the PMF by a change in the chemical weathering regime and a subsequent change in leaching of soluble species from the catchment to the lake? It can be assumed that surface soils have more time to weather and podzolise during stable periods with low erosion intensity (Mackereth, 1966). During podzolisation elements are released from primary minerals by chemical weathering, and either lost by leaching or retained through precipitation of secondary minerals or adsorption onto solid particles (Lundström et al., 2000; Sauer et al., 2007). With an increase in leaching, there should be an increased transport of soluble elements with surface runoff and groundwater into lakes where precipitation might occur. In these forms the elements are more easily leached than from their original mineral structures. The elements that are retained in the soil after weathering are also more labile, which should be reflected in the lake sediment if such soils were eroded and transported to the lake.

An inverse relationship between chemical weathering and erosion intensity is not only suggested by the aspects of the podsolisation process described above. In the case of Lake Lehmilampi, it is also telling that the lowest erosion intensities were found during warm anomalies. Weathering intensity is sensitive to changes in climate, as temperature and humidity are critical for the rate of mineral dissolution (White et al., 1999), and for the decomposition 


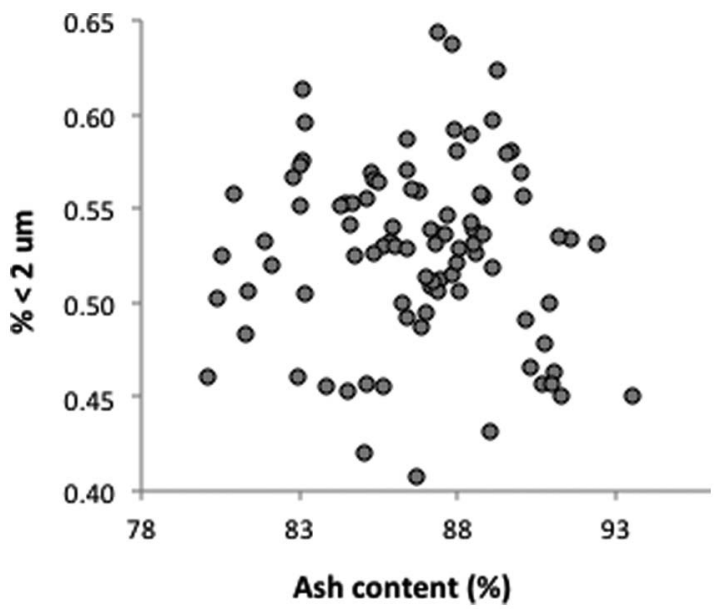

Figure 6. The percent of material in each sample that belonged to the clay sized fraction $(<2 \mu \mathrm{m})$ plotted against the erosion rate, inferred from the ash content $(n=91)$.

of organic matter (Kirschbaum, 1995), a process which releases humic acids that further stimulate weathering. An increase in temperature may have a profound effect on the annual release of elements after weathering at sites where there is snow and ice for a significant part of the year. Past weathering intensities have been deduced from lake sediments using the ratios of $\mathrm{Ca} / \mathrm{K}$ or $\mathrm{Sr} / \mathrm{Rb}$ (Chen et al., 2005; Jin et al., 2001; Kauppila and Salonen, 1997; Solovieva and Jones, 2002). These ratios can provide robust evidence of weathering intensity since they are based on common elements, of which $\mathrm{K}$ and $\mathrm{Rb}$ are primarily associated with silicates and $\mathrm{Ca}$ and $\mathrm{Sr}$ are common in carbonates. As carbonates are more readily dissolved, the ratios should decrease in the parent material as weathering proceeds. In sediments, however, the ratios increase with an increase in weathering intensity. This is because solubilised and leached $\mathrm{Ca}$ and $\mathrm{Sr}$ ions easily form secondary phases that accumulate in the sediment. $\mathrm{K}$ and $\mathrm{Rb}$, on the other hand, represent conservative elements. The fraction of these elements that is weathered remains dissolved and are thus less likely to end up in the sediment.

In Lehmilampi there is a clear negative correlation between erosion intensity and the ratios of both $\mathrm{Ca} / \mathrm{K}$ (Figure 7) and $\mathrm{Sr} / \mathrm{Rb}$, which supports the idea of weathering being more pronounced during warmer periods with low erosion intensity.

\section{Conclusions}

(1) The pollen and charcoal analyses at Lake Lehmilampi (the first to be produced from the area) suggest that the first undisputable signs of human impact and practice of slash-and-burn cultivation date to 1800 $\mathrm{BC}$ (the early Metal Period) and lasted until $100 \mathrm{BC}$. There is archaeological evidence of settlement from that period c. $1.5 \mathrm{~km}$ north of the lake catchment. The first possible palynological signs of human impact (cattle grazing) occur during the Neolithic time, c. $3000-2550 \mathrm{BC}$, which is supported by archaeological records from the area. The catchment area was probably also used for grazing from c. AD 600 to 1500 . Cereal cultivation is indicated once more from $\mathrm{AD}$ 1500 onwards and increased from AD 1700. There are three periods with low or no indication of natural or human disturbance: 3500-3000 BC, 2500-1800 BC, and $100 \mathrm{BC}$ to $\mathrm{AD} 500$.
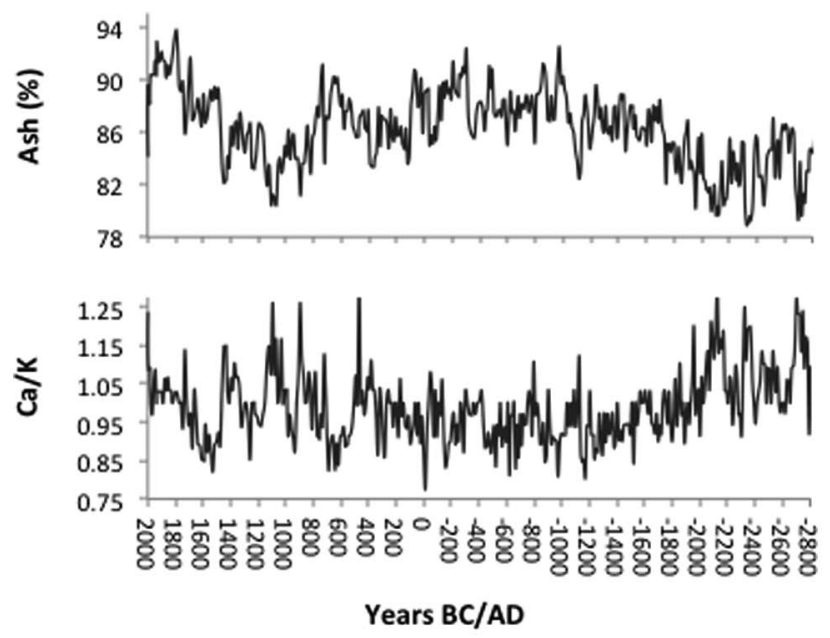

Figure 7. Variations in the $\mathrm{Ca} / \mathrm{K}$ ratio in relation to variations in estimated erosion (inferred from ash content) of the catchment area.

(2) The highest erosion intensities were found during periods with local fire and human impact (slash-and-burn cultivation), i.e. $1800-100$ BC (in particular 900-100 $\mathrm{BC}$ ) and from $\mathrm{AD}$ 1500. During periods with little (cattle grazing) or no human disturbance in the catchment, the inferred erosion intensity is lower, suggesting that destabilisation of soils related to slash-and-burn practice is the most plausible explanation for the highest erosion intensities. However, the high erosion intensities from $\mathrm{AD} 1500$ may just as well be related to the colder and more humid climate of the 'Little Ice Age' (AD 1450-1850). A climatic control is also suggested by the increase in erosion intensity at the termination of the HTM c. $2100 \mathrm{BC}$, which falls within a period with low or no indication of human impact.

(3) The lowest erosion intensities are clearly related to warm and dry climate conditions and the related effect on soil processes in the catchment during the HTM, 3500-2100 BC and the MCA (AD 950-1250). Before, during and after the MCA, i.e. the period $\mathrm{AD} 600-1500$, the disturbances inferred from the pollen and charcoal record might reflect cattle grazing, which suggests that the changes in erosion intensity during that period are more likely related to climate change than land use.

(4) The records of erosion intensity, pollen and charcoal, combined with a general knowledge of the climate history of the region, clearly show that climate change and human impact both had an impact on erosion intensity during the 5500 years of environmental history covered by the sediment sequence studied here. The HTM, its end c. $2000 \mathrm{BC}$, and the MCA were major events that had a prominent effect on erosion intensity, while human impact may have been a more decisive factor between $3000 \mathrm{BC}$ and $\mathrm{AD} 800$ as well as in recent times, from $\mathrm{AD} 1700$.

(5) Although the preserved varve sequence in Lehmilampi indicates a relatively stable environment in the lake's catchment, changes in erosion intensity were significant enough to affect the fraction of potentially mobile element phases; the latter clearly increases with decreasing erosion intensity. The increase in potentially mobile forms cannot be explained by an increased proportion of fine grained material, as no correlation was found between erosion intensity and the fraction of clay. Thus we assume that periods of low erosion inten- 
sities were associated with a higher degree of chemical weathering and leaching.

(6) Detailed geochemical studies of annually laminated lake sediments, together with pollen and charcoal analyses, have a great potential for providing an in-depth understanding of how lake-catchment erosion and related geochemical properties in lake sediments may be affected by land use and climate change; sometimes they act together, and sometimes they play contrasting roles, depending on the time period. Annually laminated sediments are particularly useful in such studies as they make it possible to date significant changes with high accuracy and thus allow a precise correlation with information from other, independent sources such as archaeological data and proxy climate records.

\section{Acknowledgements}

The authors would like to thank Teija Alenius, Department of Archaeology, University of Helsinki, for useful discussions on the interpretation of the pollen analysis in terms of human impact and providing a scheme of archaeological periods for the study area.

\section{Funding}

The study was financially supported by the Faculty of Natural Sciences and Technology, Linnaeus University.

\section{References}

Alenius T and Laakso V (2006) Palaeoecology and archaeology of the village of Uukuniemi, Eastern Finland. Acta Borealia 23: 145-165.

Alenius T, Mikkola E and Ojala AEK (2008) History of agriculture in Mikkeli Orijärvi, eastern Finland as reflected by palynological and archaeological data. Vegetation History and Archaeobotany 17: 171-183.

Augustsson A, Peltola P, Bergbäck B et al. (2010) Trace metal and geochemical variability during 5,500 years in a lake sediment from eastern Finland. Journal of Paleolimnology 44: 1025-1038.

Berglund BE and Ralska-Jasiewiczowa M (1986) Pollen analysis and pollen diagrams. In: Berglund BE (ed.) Handbook of Holocene Palaeoecology and Palaeohydrology. Chichester: John Wiley \& Sons, pp. 455-484.

Berglund BE, Gaillard MJ, Björkman L et al. (2008) Long-term changes in floristic diversity in southern Sweden: Palynological richness, vegetation dynamics and land use. Vegetation History and Archaeobotany 17: 453-472.

Berglund BE, Malmer N and Persson T (1991) Landscape-ecological aspects of long-term changes in the Ystad area. In: Berglund BE (ed.) The cultural landscape during 6000 years in southern Sweden. Ecological Bulletins 41: 405-424.

Beug HJ (2004) Leitfaden der Pollenbestimmung für Mitteleuropa und angrenzende Gebiete. München: Verlag Dr Friedrich Pfeil.

Birks HJB and Line JM (1992) The use of rarefaction analysis for estimating palynological richness from Quaternary pollen-analytical data. The Holocene 2: 1-10.

Broström A, Gaillard MJ, Ihse M et al. (1998) Pollen-landscape relationships in modern analogues of ancient cultural landscapes in southern Sweden - A first step towards quantification of vegetation openness in the past. Vegetation History and Archaeobotany 7: 189-201.

Chen J, Wan G, Dian Zhang D et al. (2005) The 'Little Ice Age' recorded by sediment chemistry in Lake Erhai, southwest China. The Holocene 15: 925-931.

Cornell JD (2007) Slash and Burn. The Encyclopedia of Earth (EoE). www. eoearth.org

Dahl SO and Nesje A (1996) A new approach to calculating Holocene winter precipitation by combining glacier equilibrium-line altitudes and pine-tree limits: A case study from Hardangerjøkulen, central southern Norway. The Holocene 6: 381-398.

Digerfeldt G (1988) Reconstruction and regional correlation of Holocene lake-level fluctuations in Lake Bysjön, South Sweden. Boreas 17: 165-182.

Dotterweich M (2008) The history of soil erosion and fluvial deposits in small catchments of central Europe: Deciphering the long-term interaction between humans and the environment - A review. Geomorphology 101: 192-208.
Enters D, Dörfler W and Zolitschka B (2008) Historical soil erosion and land use change during the last two millennia recorded in lake sediments of Frickenhauser See, northern Bavaria, central Germany. The Holocene 18: 243-254.

Eronen M, Hyvärinen H and Zetterberg P (1999) Holocene humidity changes in northern Finnish Lapland inferred from lake sediments and submerged Scots pines dated by tree-rings. The Holocene 9: 569-580.

Finland's National Board of Antiquities (2012) Online database of cultural heritage. Available at: kulttuuriymparisto.nba.fi/netsovellus/rekisteriportaali/portti/default.aspx

Gaillard M-J (2007) Pollen methods and studies: archaeological applications. In: Elias SA (ed.) Encyclopedia of Quaternary Science (Volume 3). Amsterdam: Elsevier, pp. 2575-2595.

Greisman A and Gaillard MJ (2008) The role of climate variability and fire in early and mid Holocene forest dynamics of southern Sweden. Journal of Quaternary Science 24: 593-611.

Grimm E (1987) Coniss: A FORTRAN 77 program for stratigraphical constrained cluster analysis by the method of incremental sum of squares. Computers \& Geosciences 13: 13-37.

Grimm E (1990) TILIA and TILIA.GRAPH: PC spreadsheet and graphics software for pollen data. INQUA Commission for the Study of the Holocene Working Group on Data Handling Methods Newsletter 4: 5-7.

Grönlund E (1995) A palaeoecological study of land use history in East Finland. $\mathrm{PhD}$ Thesis University of Joensuu, Publications in Sciences 31.

Grönlund E and Asikainen E (1992) Reflections of slash-and-burn cultivation cycles in a varved sediment of Lake Pitkälampi (North Karelia). Laborativ Arkeologi 6: 43-48.

Grönlund E, Poutiainen H and Koponen M (1992) Pollen and pottery: On the traces of settlement and land use history of North Karelia, East Finland. Arkaeologiske rapporter fra Esberg Museum 1992: 169-175.

Haegström CA (1990) The influence of sheep and cattle grazing on wooded meadows in Åland, SW Finland. Acta Botanica Fennica 141: 1-28.

Hall GEM (1998) Analytical perspective on trace element species of interest in exploration. Journal of Geochemical Exploration 61: 1-19.

Hall GEM, Vaive JE, Beer R et al. (1996) Selective leaches revisited, with emphasis on the amorphous Fe oxyhydroxide phase extraction. Journal of Geochemical Exploration 56: 59-78.

Haltia-Hovi E, Nowaczyk N, Saarinen T et al. (2010) Magnetic properties and environmental changes recorded in Lake Lehmilampi (Finland) during the Holocene. Journal of Paleolimnology 43: 1-13.

Haltia-Hovi E, Saarinen T and Kukkonen M (2007) A 2000-year record of solar forcing on varved lake sediment in eastern Finland. Quaternary Science Reviews 26: 678-689.

Hammarlund D, Björck S, Buchardt B et al. (2003) Rapid hydrological changes during the Holocene revealed by stable isotope records of lacustrine carbonates from Lake Igelsjön, southern Sweden. Quaternary Science Reviews 22: 353-370.

Heikkilä M and Seppä H (2003) A 11,000 yr palaeotemperature reconstruction from the southern boreal zone in Finland. Quaternary Science Reviews 22: $541-554$

Hellman S, Bunting MJ and Gaillard M-J (2009a) Relevant Source Area of Pollen in patchy cultural landscapes and signals of anthropogenic landscape disturbance in the pollen record: A simulation approach. Review of Palaeobotany and Palynology 153: 245-258.

Hellman S, Gaillard M-J, Bunting MJ et al. (2009b) Relevant source area of pollen in past cultural landscapes - A forward modelling approach. Review of Palaeobotany and Palynology 153: 259-271.

Itkonen A and Salonen V-P (1994) The response of sedimentation on three varved lacustrine sequences to air temperature, precipitation and human impact. Journal of Paleolimnology 11: 323-332.

Jessen CA, Rundgren M, Björck S et al. (2005) Abrupt climatic changes and an unstable transition into a late Holocene Thermal Decline: A multiproxy lacustrine record from southern Sweden. Journal of Quaternary Science 20: $349-362$

Jin Z, Wang S, Shen J et al. (2001) Chemical weathering since the Little Ice Age recorded in lake sediments: A high-resolution proxy of past climate. Earth Surface Processes and Landforms 26: 775-782.

Jones KPN, McCave IN and Patel PD (1988) A computer interfaced sedigraph for modal size analysis of fine-grained sediment. Sedimentology 35: $163-172$.

Kauppila T and Salonen V-P (1997) The effect of Holocene treeline fluctuations on the sediment chemistry of Lake Kilpisjärvi, Finland. Journal of Paleolimnology 18: 145-163.

Kirschbaum MUF (1995) The temperature dependence of soil organic matter decomposition, and the effect of global warming on soil organic $\mathrm{C}$ storage. Soil Biology \& Biochemistry 27: 753-760. 
Korhola A (1995) Holocene climatic variations in southern Finland reconstructed from peat-initiation data. The Holocene 5: 43-58.

Korhola A, Alm J, Tolonen K et al. (1996) Three-dimensional reconstruction of carbon accumulation and $\mathrm{CH} 4$ emission during nine millennia in a raised mire. Journal of Quaternary Science 11: 161-165.

Lundström US, van Breemen N and Bain D (2000) The podzolization process. A review. Geoderma 94: 91-107.

Luukkonen E (2003) Geological map of Finland. Sheet 4321, Nurmes. Geological Survey of Finland.

Mackereth FJH (1966) Some chemical observations on post-glacial lake sediments. Philosophical Transactions of the Royal Society of London. Series B, Biological Sciences 250: 165-213.

Mann M, Zhang ZH, Rutherford S et al. (2009) Global signatures and dynamical origins of the Little Ice Age and Medieval Climate Anomaly. Science 326: 1256-1260.

Nesje A, Matthews JA, Dahl SO et al. (2001) Holocene glacier fluctuations of Flatebreen and winter-precipitation changes in the Jostedalsbreen region, western Norway, based on glaciolacustrine sediment records. The Holocene 11: 267-280.

Ojala A and Alenius T (2005) 10000 years of interannual sedimentation recorded in the Lake Nautajärvi (Finland) clastic-organic varves. Palaeogeography, Palaeoclimatology, Palaeoecology 219: 285-302.

Ojala AEK and Francus P (2002) Comparing x-ray densitometry and BSEimage analysis of thin section in varved sediments. Boreas 31: 57-64.

Pitkänen A (1999) Palaeoecological study of the history of forest fires in eastern Finland. PhD thesis, University of Joensuu. Publications in Sciences 58 .

Pitkänen A, Huttunen P, Jungner H et al. (2002) A 10000 year local forest fire history in a dry heath forest site in eastern Finland, reconstructed from charcoal layer records of a small mire. Canadian Journal of Forest Research 32: 1875-1880.

Poutiainen H, Grönlund E, Koponen M et al. (1994) Havaintoja pohjois-karjalan asutus - ja viljelyhistoriasta. Kentältä poimittua 2: 70-75 (in Finnish).

Punt W (1976-2003) The Northwest European Pollen Flora I-VIII. Amsterdam: Elsevier Scientific.

Renberg I, Segerström U and Wallin J-E (1984) Climatic reflection in varved lake sediments. In: Mörner N-A and Karlén W (eds) Climatic Changes on a Yearly to Millennial Basis. Dordrecht: Reidel, pp. 249-256.
Sauer D, Sponagel H, Sommer M et al. (2007) Review Article Podzol: Soil of the Year 2007 A review on its genesis, occurrence, and functions. Journal of Plant Nutrition and Soil Science 170: 581-597.

Seppä H, Bjune AE, Telford RJ et al. (2009) Last nine-thousand years of temperature variability in Northern Europe. Climate of the past Discussions 5: 1521-1552.

Seppä H, Hammarlund D and Antonsson K (2005) Low-frequency changes in temperature and effective humidity during the Holocene in south-central Sweden: Implications for atmospheric and oceanic forcings of climate. Climate Dynamics 25: 285-297.

Solovieva N and Jones VJ (2002) A multiproxy record of Holocene environmental changes in the central Kola Peninsula, northwest Russia. Journal of Quaternary Science 17: 303-318.

Stockmarr J (1971) Tablets with spores used in absolute pollen analysis. Pollen Spores 13: 615-621.

Sugita S (1994) Pollen representation of vegetation in Quaternary sediments: Theory and method in patchy vegetation. Journal of Ecology 82: 881-897.

Sugita S (2007) Theory of quantitative reconstruction of vegetation. II. All you need is LOVE. The Holocene 17: 243-257.

Sugita S, Gaillard MJ and Broström A (1999) Landscape openness and pollen records: A simulation approach. The Holocene 9: 409-421.

Tiljander M, Saarnisto M, Ojala AK et al. (2003) A 3000-year palaeoenvironmental record from annually laminated sediment of Lake Korttajärvi, central Finland. Boreas 32: 566-577.

Vuorela I (1999) The beginnings of agricultural land use in Finland: An assessment based on palynological data. Pact 57: 339-351.

Vuorela I and Kankainen T (1993) Luonnon a kulttuurimaiseman kehhitys Taipalsaaressa. Geologian tutkimuskeskus. Maaperä-osasto. Raportii P. 34.4.107, pp. 1-46 (in Finnish).

Wetzel RG (2001) Limnology: Lake and River Ecosystems. Third Edition. Academic Press.

White AF, Blum AB, Bullen TD et al. (1999) The effect of temperature on experimental and natural chemical weathering rates of granitoid rocks. Geochimica et Cosmochimica Acta 63: 3277-3291.

Zolitschka B (2003) Human and climatic impact on the environment as derived from colluvial, fluvial and lacustrine archives - Examples from the Bronze Age to the Migration period, Germany. Quaternary Science Reviews 22: 81-100. 
Copyright of Holocene is the property of Sage Publications, Ltd. and its content may not be copied or emailed to multiple sites or posted to a listserv without the copyright holder's express written permission. However, users may print, download, or email articles for individual use. 